\title{
Factors affecting employee commitment of office staff in Ho Chi Minh City
}

\author{
Nguyen Quoc Cuong ${ }^{1 *}$, Vo Thuc Uyen ${ }^{1}$, Nguyen Thi Thanh Nhan ${ }^{2}$ \\ ${ }^{1}$ Industrial University of Ho Chi Minh City, Vietnam \\ ${ }^{2}$ FPT University, Saigon Hi-tech Park, Thu Duc City, Vietnam \\ *Corresponding author: nguyenquoccuong@iuh.edu.vn
}

\section{ARTICLE INFO}

DOI: $10.46223 /$ HCMCOUJS.

econ.en.12.1.2022.2022

Received: August $01^{\text {st }}, 2021$

Revised: September $20^{\text {th }}, 2021$

Accepted: September $30^{\text {th }}, 2021$

Keywords:

EFA; employee commitment; offce staff; human resource development

\section{ABSTRACT}

This paper examined the factors affecting the commitment of office staff in Ho Chi Minh City (HCMC). The data is collected through questionnaires from 253 office staff; the SPSS software is used to analyse data through Cronbach's Alpha reliability testing method, Exploratory Factor Analysis (EFA), and regression analysis. The research results revealed that training and development opportunities, salary and bonuses, and employee benefits are three critical factors that positively affect the commitment of office staff to the enterprise. The study provides implications or strategies for managers to improve their human resource management and enhance long-term employee commitment. Besides, the study also provides recommendations for future research.

\section{Introduction}

Human Resource (HR) is one of the most critical resources that significantly influence the organisation's success. Human resource managers strategically implement many practices to promote employees' commitment to organisations. Man and Harter (2016) show that companies in the top quintile with high employee commitment, compared to companies in the bottom, their profits are 22\% higher and 10\% higher for rank customers (EMSC, 2019). Jaw and Liu (2004) insist that committed employees are increasingly becoming a valuable asset in organizations, and commitment is not only a human relation concept but involves generating human energy and activating the human mind. Besides, John and Elyse (2010) confirm that without commitment, the implementation of new ideas and initiatives will be compromised. Izogo, Elom, and Mpinganjira (2020) also demonstrated that employee commitment to service and customer engagement significantly influences customer value elements. Agyeiwaah, Zhou, and Dayour (2021) suggest that employee commitment affects customer satisfaction and behavioural intentions. Human resource managers and recruitment experts have been paying more attention to improving longterm employee commitment. However, the factors influencing employee commitment have not been intensively researched among Vietnamese office staff. Therefore, the objective of this research is to identify the factors affecting the employee commitment of office staff to enterprises in Ho Chi Minh City. The theoretical contribution of this paper are to empirically assess the factors affecting employee commitment in their organisations. Besides, the managerial implications of this research are to help businesses overcome the disadvantages and improve the advantages in human resource management strategies. 


\section{Literature review and research hypothesis}

\subsection{Theoretical basis}

\subsubsection{Employee commitment}

Organisational commitment is defined as the psychological connection between an individual and their organisation that makes them less likely to leave the organisation voluntarily (Allen \& Meyer, 1996). Employee commitment becomes an important issue in business because the enterprise tries to produce more output without increasing many labours. Based on reality, businesses must find ways to commit employees physically at work and mentally and spiritually loyalty (Izogo et al., 2020). According to the Three-Component Model (TCM) of Commitment (Allen \& Meyer, 1990; Meyer \& Allen, 1991), commitment can take many forms, and a psychological state or different thinking characterises each form; affective commitment, normative commitment, and continuing commitment. All three forms of commitment bind an individual to the organisation and reduce the cost of leaving, but their implications for work behaviour can be different. Working commitment includes mental states expressed about employees' thoughts, words, and actions with work: that is, attention to work, dedication to work, work with passion and enthusiasm, dedication to work, effort and energy to work (T. Q. Tran, 2016). Employees who are engaged in their work are energised and confident through the events of their lives. With a positive level of activity and attitude, these employees receive appreciation, recognition, and success. Although this type of person feels tired after a long day at work, they describe this fatigue as a pleasant, well-deserved state associated with the positive results they achieve (T. Q. Tran, 2016). Commitment is a positive attitude of employees towards the organisation and the value that employees receive when working and working with colleagues to improve performance at work. Businesses to grow and maintain need workers, so a two-way relationship between enterprises and employees is established.

\subsubsection{The importance of employee commitment}

Nowadays, one of the competitive advantages among companies is creative and wellthought-out human resources. Finding out talents has been difficult until now, but keeping the best talents is even more challenging. When businesses lose talented employees who work with high efficiency, it means that the organisation must spend more time replacing workers, not to mention wages, and organisations also must suffer from the loss of employees hire a replacement because each employee who moves out brings with him the values of human capital, knowledge, skills and even know-how of the organisation. Therefore, the importance of talent management is recognised. Yapp (2009) showed that a working environment that could create intense competition among talented people would promote organisations and agencies to invest more in talent activities; investment met the immediate need for resources and ensured a sustainable leadership system. No investing in humans will lead to negative consequences for current human resources and negatively affect operational results such as productivity, quality, and customer service, especially brand and business organisation's existence and development (Yapp, 2009). MaceyDare (2009) argued that no company could win in the long run without motivated employees who believed in the company's mission and understood how to accomplish that mission. Besides that, Bhatnagar (2007) observed that employees who stay with the organisation could create a competitive advantage for their organisation, as explained from the organisational resource-based perspective. Employees who have been working for the organisation will become assets and strengths, serving the organisation's sustainable competitive advantage. For any organisation, both talented employees and their commitment to the organisation play an essential role. They are related to a "soft" approach to human resource management while promoting competitive 
advantages and stimulating positive contributions. Thus, the formula can be drawn as follows: "Talent + Organisational commitment = Labor efficiency and success" of the organisation $(\mathrm{N}$. V. Tran, 2015).

\subsection{Factors affecting employee commitment}

\subsubsection{Working environment}

The working environment is the conditions surrounding all activities of an employee in the organisation. The working environment includes relevant physical and mental conditions that affect the working process and development of employees. Businesses need to create a healthy and safe working environment with an exciting and comfortable atmosphere because employees are most of the time at the company. If the working environment is unsafe, uncomfortable, stuffy, employees will fall into a state of depression and insecurity. That reduces the ability to work, reduces productivity. To create a safe and comfortable working environment, enterprises need to improve working conditions and overcome those that adversely affect employees. T. P. T. Do, Nguyen, and Nguyen (2012) presented that the working environment is one factor that creates employees' commitment to the enterprises. Teo, Bentley, and Nguyen (2020) demonstrated that workplace psychology moderates job commitment and employee engagement. T. T. Nguyen and Ho (2021) have shown that the working environment directly positively affects job satisfaction, organisational commitment, and intention to stay in the organisation. Therefore, hypothesis 1 of this study is stated as follows:

\section{H1: Working environment positively affects employee commitment}

\subsubsection{Relationships with colleagues}

Relationships with colleagues are the interaction between employees in the organisation to support and share in work through cooperation, taking care of together, or helping. The importance of relationships with colleagues is mentioned in the psychosocial literature. Interpersonal relationships have been found to impact many types of outcomes, such as academic achievement (Véronneau, Vitaro, Brendgen, Dishion, \& Tremblay, 2010), personal achievement (Fernet, Gagné, \& Austin, 2010), and prejudice patterns (Paolini, Hewstone, \& Cairns, 2007). Basford and Offermann (2012) argued that positive coworker relationships increase employees' motivation and intention to stay. Ha and Bui (2016) also pointed out that communication in the organisation and teamwork are corporate cultural factors affecting employee's commitment to the company. Teo et al. (2020) also support the view that relationships with colleagues impact employee commitment to the enterprise. Therefore, hypothesis 2 of this study is stated as follows:

\section{H2: Relationship with colleagues has a positive impact on employee commitment}

\subsubsection{Training and development opportunities}

According to D. V. Nguyen and Nguyen (2007), training and development are activities to maintain and improve the quality of the organisation's human resources, which is a decisive condition for organisations to stand firm in the competitive environment. Undeniably, training and development provide businesses with high-quality human capital, contributing to improving competitiveness. Training courses that provide managers or employees with new knowledge are a typical type of development (D. K. Tran, 2003). Moreover, the development includes activities that prepare employees to keep up with the organisational structure as it changes and evolves. Some enterprises create development opportunities for employees through training to help them improve their professional and professional skills. It meets the need for self-improvement as in Maslow's theory (1954). Therefore, employees need the opportunities to learn new skills, be applied for higher promotion, have training and development programs, and be recognised by their 
superiors for their achievements. Some previous studies have demonstrated a positive relationship between training and development and employee commitment (A. T. K. Nguyen, Nguyen, \& Do, 2018; C. Nguyen \& Duong, 2020). Moreover, Ha and Bui (2016) also showed that training and development are corporate cultural factors affecting employees' commitment to the enterprise. Therefore, hypothesis 3 of this study is stated as follows:

\section{commitment}

H3: Training and development opportunities have a positive relationship to employee

\subsubsection{Salary and bonuses}

Salary is one factor that stimulates people to work enthusiastically, but it is also one of the causes of stagnation, dissatisfaction, or leaving the company. It depends on the level and capacity of the administrators (T. H. Nguyen, 2006). Salaries are determined based on an agreement between the employee and the employer based on the job position, the job's complexity, the scope of the job's responsibilities, and the qualification requirements, skills and experience of the person performing the job. The salary paid to the employees must ensure that their daily needs are met and must ensure the life of their family members. When the salary can reach the needs of employees, they will feel more secure during the working process. The salary is paid to employees must be determined based on their work performance so that it is commensurate with the employees' contributions to the company to ensure fairness in wages. According to Article 104 of the Labor Law 2019 (National Assembly, 2021), the bonus is the amount of money or property or other forms that the employer rewards the employee based on the production and business results and the degree of successful completion of the work. Bonuses are used to strongly stimulate and motivate employees to dedicate themselves and create in working at the enterprise. This policy is also considered a motivation to attract good employees, stabilise human resources, and develop the company's quality of labour. Besides that, the bonus helps businesses create competitive advantages (National Assembly, 2021). Furthermore, previous studies also confirmed that salary and bonuses positively influence employees' long-term commitment to the enterprise (Do et al., 2012; Ho \& Nguyen, 2018; N. P. Nguyen, Nguyen, Nguyen, \& Hoang, 2020; Pham \& Nguyen, 2013). So, hypothesis 4 of this study is stated as follows:

\section{H4: Salary and bonuses have a positive impact on employee commitment}

\subsubsection{Employee benefits}

According to D. K. Tran (2003), employee benefit is an indirect remuneration paid indirectly in life support for employees. Employee benefit shows the concern of the enterprise to the lives of employees, stimulating employees to be loyal and commit to the enterprise. Employee benefits of the enterprise include social insurance, health insurance, unemployment insurance, retirement, vacation, holiday, enterprise allowance for employees, corporate gifts for employees on birthdays and weddings. The State regulates compulsory social insurance in enterprises; employees are entitled to social insurance benefits, sickness, occupational accident, occupational disease, maternity, retirement, and death benefits. Most allowances are usually calculated based on assessing the impact of an unfavourable working environment on the health and comfort of employees at the workplace. Do et al. (2012) proved that reward and welfare positively affect employee commitment in Vietnam. Some previous studies have confirmed a positive relationship between employee welfare and long-term commitment to the enterprise (A. T. K. Nguyen et al., 2018; N. P. Nguyen et al., 2020; Pham \& Nguyen, 2013). Based on the literature review, hypothesis H5 is stated as follows: 
H5: Employee benefits have a positive impact on employee commitment

\subsubsection{The proposed conceptual framework}

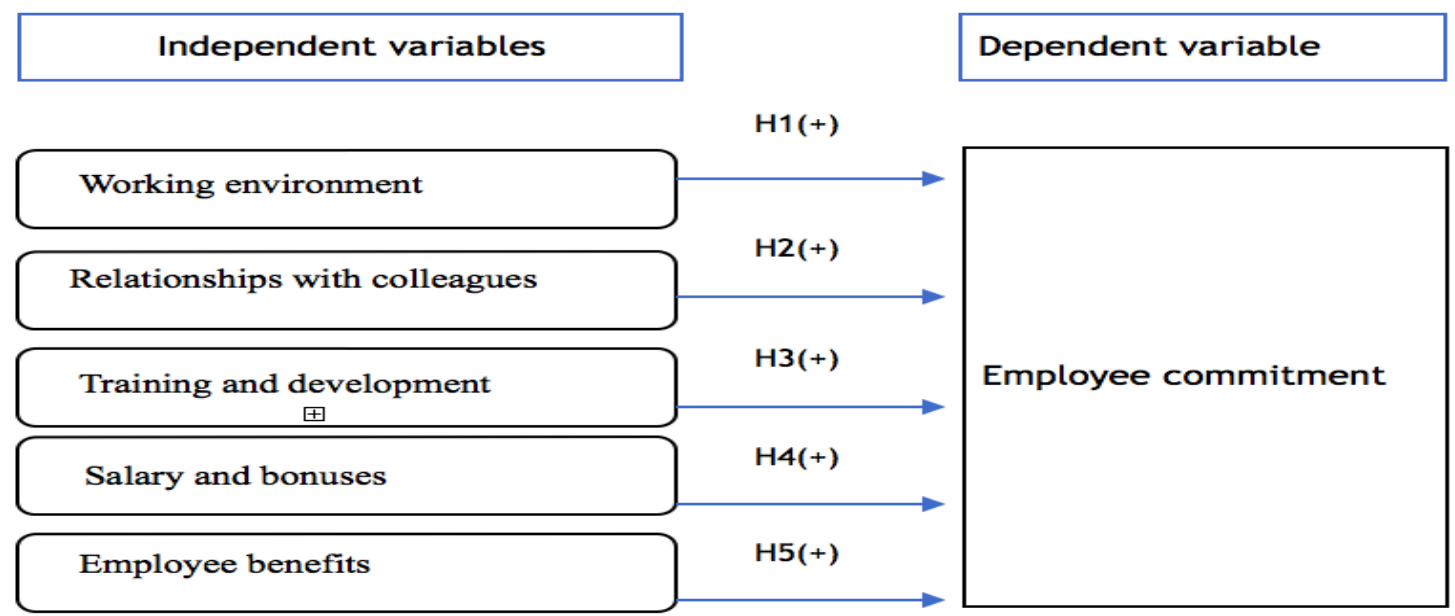

Figure 1. Conceptual framework

\section{Research methods}

When it comes to data collection and analysis, the study experienced in 03 stages.

Stage 1: Preparing items and questions

After discussing with human resources experts and evaluating the literature review, independent variables are Working environment (MT), salary and bonuses (LT), relationship with colleagues (DN), Employee benefits (PL), Training and development opportunities (CH). The dependent variable is Employee commitment (GB). Items for each variable are mentioned in the appendix.

Stage 2: Designing the questionnaires in detail

The questionnaire is developed according to items of factors affecting employee commitment in business in Ho Chi Minh City, including two sections. The first section is for sociodemographic questions such as gender, age, education level, seniority, income from the current job. The second one is related to the independent and dependent variables using the 5-Point Likert scale $(1=$ Totally disagree, $2=$ Disagree, $3=$ Neutral, $4=$ Agree, $5=$ Totally agree $)$.

Stage 3: Conducting the survey

The questionnaire will be designed on Google Docs. After that, it will be sent to employees via email addresses or social networking channels (Groups of office staff working in HCMC). Based on the theory for econometrics, the sample size for the exploratory factor analysis (EFA) must be at least 04 or 05 times the number of observed variables (Hoang \& Chu, 2008). For the topic, all 30 items need to be estimated. So, the minimum number of samples needed is $30 \times 6=$ 180 participants. The author collected 300 surveys for office staff in HCMC using data collection methods through online surveys or face-to-face personal interviews. After collecting data, the reliable sample is 253 participants. It was imported into SPSS software, and Cronbach's alpha coefficient was used to test the reliability of the items. Exploratory Factor Analysis (EFA) is applied to data reduction into factors in which the items are closely related. The multiple linear regression analysis is applied to test relationships between independent and dependent variables. The author analyses the data and uses the deductive-inductive method to conclude and give appropriate management implications. 


\section{Research results}

\subsection{Descriptive statistics}

\subsubsection{Gender}

\section{Table 1}

Gender's respondents

\begin{tabular}{|l|l|}
\hline Gender & Percentage \\
\hline Male & $39.53 \%$ \\
\hline Female & $60.47 \%$ \\
\hline
\end{tabular}

Source: Author's calculations

The data shows that the number of female employees accounts for a higher proportion of $60.47 \%$, and the number of male employees with a lower percentage account for $39.53 \%$.

$$
\text { 4.1.2. Age }
$$

\section{Table 2}

Age range's respondents

\begin{tabular}{|l|l|}
\hline Age range & Percentage \\
\hline 22 to 30 & $84.58 \%$ \\
\hline 31 to 45 & $11.46 \%$ \\
\hline Over 45 & $3.95 \%$ \\
\hline
\end{tabular}

Source: Author's calculations

The descriptive statistical results show that employees aged from 22 to 30 years old account for the maximum rate of $84.58 \%$, followed by the age group from 31 to 45 years old accounted for $11.46 \%$, and the minimum rate is from 31 to 45 years old. The age group over 45 years old accounts for $3.95 \%$. The results show that if businesses want to create a long-term commitment, they should focus on 22 to 30 years old employees.

\subsubsection{Academic level}

\section{Table 3}

Academic level's respondents

\begin{tabular}{|l|l|}
\hline Academic level & Percentage \\
\hline College & $21.74 \%$ \\
\hline University & $76.28 \%$ \\
\hline Postgraduate & $1.98 \%$ \\
\hline
\end{tabular}

Source: Author's calculations

Descriptive statistics show that employees with university education account for the maximum $76.28 \%$, followed by intermediate and college education accounting for $21.74 \%$. Moreover, the minimum is post-graduate, accounting for $1.98 \%$. 


\subsubsection{Working department}

\section{Table 4}

Working department's respondents

\begin{tabular}{|l|l|}
\hline Working department & Percentage \\
\hline Accounting & $35.97 \%$ \\
\hline Human resources & $23.32 \%$ \\
\hline Administration & $16.6 \%$ \\
\hline Other departments & $7.11 \%$ \\
\hline
\end{tabular}

Source: Author's calculations

The data shows that accounting department staff accounted for the maximum $35.97 \%$, followed by human resources department staff $23.32 \%$, administrative department staff $16.6 \%$, sales department staff $17 \%$ and the minimum group in other departments is $7.11 \%$.

\subsubsection{Position in the company}

\section{Table 5}

Position's respondents

\begin{tabular}{|l|l|}
\hline Positions & Percentage \\
\hline Employee & $95.26 \%$ \\
\hline Middle managers & $3.56 \%$ \\
\hline Top managers & $1.19 \%$ \\
\hline
\end{tabular}

Source: Author's calculations

The maximum level of employees is $95.26 \%$, the second is middle managers, about $3.56 \%$, and the minimum is top managers, $1.19 \%$.

\subsubsection{Monthly income from current job}

Table 6

Monthly income's respondents

\begin{tabular}{|l|l|}
\hline Monthly Income & Percentage \\
\hline Less than 05million VND & $18.97 \%$ \\
\hline $05-10$ million VND & $53.75 \%$ \\
\hline $10-15$ million VND & $23.32 \%$ \\
\hline More than 20million VND & $3.95 \%$ \\
\hline
\end{tabular}

Source: Author's calculations

Office staff in Ho Chi Minh City have a monthly income of 05 - 10million VND, accounting for a maximum of 53.75\%. The income level from 10 to 15 million VND accounts for 
$23.32 \%$, the income level < 05million VND accounted for $18.97 \%$, and the minimum level is the income level $>20$ million VND accounted for $3.95 \%$.

\subsubsection{Working years}

\section{Table 7}

Respondent's working years

\begin{tabular}{|l|l|}
\hline Amount of Working Years & Percentage \\
\hline Less than 01 year & $30.83 \%$ \\
\hline 01 to 03 years & $41.11 \%$ \\
\hline 03 to 05 years & $1.19 \%$ \\
\hline More than 05 years & $26.88 \%$ \\
\hline
\end{tabular}

Source: Author's calculations

The seniority of $01-03$ years accounted for $41.11 \%$; the seniority of less than 01 year, the second-maximum accounted for $30.83 \%$; employees over 05 years accounted for $26.88 \%$. The minimum is seniority from 03 years to 05 years, accounting for $1.19 \%$.

\subsection{Evaluating the reliability of the scale using Cronbach's Alpha}

\section{Table 8}

Evaluate the reliability of the scale using Cronbach's Alpha

\begin{tabular}{|c|c|c|c|}
\hline Variable & Number of items & $\begin{array}{c}\text { Cronbach's Alpha. } \\
\text { coefficient }\end{array}$ & $\begin{array}{c}\text { The smallest correlation } \\
\text { with the total variable }\end{array}$ \\
\hline Working environment & 5 & 0.828 & 0.503 \\
\hline Salary and bonuses & 5 & 0.840 & 0.681 \\
\hline $\begin{array}{c}\text { Relationship with } \\
\text { colleagues }\end{array}$ & 5 & 0.888 & 0.664 \\
\hline $\begin{array}{c}\text { Training and } \\
\text { development } \\
\text { opportunities }\end{array}$ & 5 & 0.840 & 0.517 \\
\hline Employee benefits & 5 & 0.865 & 0.548 \\
\hline Employee commitment & 5 & 0.850 & 0.640 \\
\hline
\end{tabular}

Source: Author's SPSS Output

The correlation coefficient of all variables is greater than 0.3 , so all variables are accepted. The observed variables all meet the standards of reliability, ensuring good quality. These items will be included in the exploratory factor analysis. 


\subsection{Exploratory Factor Analysis (EFA)}

\section{Table 9}

Exploratory Factor Analysis

\begin{tabular}{|l|l|l|c|c|}
\hline & KMO & Sig. & $\begin{array}{c}\text { Total variance } \\
\text { extracted (\%) }\end{array}$ & Factor Loading factor \\
\hline 1. Independent variables & 0.868 & 0.000 & 68.588 & $0.691-0.788$ \\
\hline Salary and bonuses & & & & $0.652-0.851$ \\
\hline Employee benefits & & & & $0.634-0.867$ \\
\hline Relationship with colleagues & & & & $0.567-0.780$ \\
\hline Working environment & & & & $0.783-0.647$ \\
\hline $\begin{array}{l}\text { Training and development } \\
\text { opportunities }\end{array}$ & & & & $0.774-0.816$ \\
\hline 2. Dependent variable & 0.839 & 0.000 & 62.621 & \\
\hline Employee commitment & & & & \\
\hline
\end{tabular}

Source: Author's SPSS Output

After analysing Exploratory Factor Analysis (EFA) for the independent variable, the findings are as follows:

The first time, total variance extracted equals $68.588 \%$, which is higher than $50 \%$ which means that the 05 extracted factors explain $68.588 \%$ of the variation of the observed data. However, items $\mathrm{CH} 4$ and $\mathrm{CH} 5$ were excluded because of non-converging.

The second time results present that all observed variables have factor loading, which is higher than 0.5. It is satisfactory, showing that the factor variable and observed variable are closely related.

- Factor F1 includes 05 items (LT3, LT5, LT4, LT1, LT2) named "Salary and bonuses"

- Factor F2 includes 05 items (PL4, PL3, PL2, PL1, PL5) named "Employee benefits"

- Factor F3 includes 05 items (DN4, DN5, DN3, DN2, DN1) named "Relationships with colleagues"

- Factor F4 includes 05 items (MT1, MT2, MT4, MT5, MT3) named "Working environment"

- Factor F5 includes 03 items $(\mathrm{CH} 2, \mathrm{CH} 1, \mathrm{CH} 3)$ named "Training and development opportunities"

All items belong to their factor, except for factor F5 (excluding $\mathrm{CH} 4, \mathrm{CH} 5$ ), so the name remains the same as at the beginning. These factors will be included in the regression analysis.

After running EFA for the dependent variable, "GB" is measured by 05 items belonging to one factor. 


\subsection{Correlation analysis and linear regression analysis}

\section{Table 10}

Correlation Analysis and Linear Regression

\begin{tabular}{|l|l|l|l|l|l|}
\hline & \multicolumn{1}{|c|}{$\mathbf{t}$} & \multicolumn{1}{|c|}{$\boldsymbol{\beta}$} & \multicolumn{1}{c|}{ Sig. } & \multicolumn{1}{c|}{ VIF } & \multicolumn{1}{c|}{ Pearson } \\
\hline (Constant) & 5.892 & 1.170 & .000 & & \\
\hline F_MT & -.027 & -.001 & .979 & 1.449 & $.372 * *$, sig. $=0.000$ \\
\hline F_DN & -1.364 & -.056 & .174 & 1.582 & $.383 * *$, sig. $=0.000$ \\
\hline F_CH & 7.856 & .308 & .000 & 1.565 & $.625 * *$, sig. $=0.000$ \\
\hline F_PL & 2.805 & .109 & .005 & 1.105 & $.226 * *$, sig. $=0.000$ \\
\hline F_LT & 7.234 & .363 & .000 & 1.806 & $.626 * *$, sig. $=0.000$ \\
\hline
\end{tabular}

Sig coefficient. (ANOVA): 0.000

R2 correction: 0.523

Note: $* * \mathrm{p}<0.01$

Source: Author's SPSS Output

The coefficients of variance exaggeration VIF of the variables are from 1.105 to 1.806 less than 2 , showing that the regression model does not have multicollinearity. The model has statistical significance. The Sig. coefficient of the variables including training and development opportunities, salary and bonuses, and employee benefits are smaller than 0.05 , so these three hypotheses are accepted. Among the 03 independent variables, training and development opportunities, salary and bonuses, and employee benefits, coefficients Beta $>0$ show that these independent variables positively influence the dependent variable. Besides, the Sig coefficient of the variable working environment, relationship with colleagues is higher than 0.05; hypotheses are rejected. The multiple regression equation is stated as follow:

$$
\mathrm{GB}=1.170+0.308 \mathrm{CH}+0.109 \mathrm{PL}+0.363 \mathrm{LT}
$$

\subsection{Discussions}

The model shows that five independent variables have only three factors that positively affect employees' long-term commitment at 95\% confidence ( $\mathrm{sig}<0.05$ ), and the remaining two factors negatively influence employee commitment. Salary and bonuses are the maximum levels of influence. It has a beta coefficient of 0.363 , which means employees' long-term commitment will increase many businesses pay employees. Through the regression equation, training and development opportunities with a beta coefficient of 0.308 are the second-maximum level influence. It proves that long-term employee commitment will increase if businesses create conditions for employees to develop through training and development. Employee benefit has a beta coefficient of 0.109 . It is the third level of influence, which means that when businesses want to enhance employee commitment for a long time, they must offer clear and attractive welfare policies. 


\section{Table 11}

Hypothesis test results

\begin{tabular}{|c|c|c|c|}
\hline & Hypotheses & Correlation & Results \\
\hline H1 & $\begin{array}{l}\text { The working environment has a positive } \\
\text { effect on employee commitment. }\end{array}$ & $(-)$ & Rejected \\
\hline H2 & $\begin{array}{l}\text { Relationships with colleagues have a positive } \\
\text { effect on employee commitment. }\end{array}$ & $(-)$ & Rejected \\
\hline H3 & $\begin{array}{l}\text { Training and development opportunities have } \\
\text { a positive effect on employee commitment. }\end{array}$ & $(+)$ & Accepted \\
\hline H4 & $\begin{array}{l}\text { Salary and bonuses have a positive effect on } \\
\text { employee commitment. }\end{array}$ & $(+)$ & Accepted \\
\hline H5 & $\begin{array}{l}\text { Employee benefits have a positive effect on } \\
\text { employee commitment. }\end{array}$ & $(+)$ & Accepted \\
\hline
\end{tabular}

Source: Author's SPSS Output

\section{Conclusion}

\subsection{Implications}

The research objective is to measure and evaluate the influence of each factor, thereby offering some solutions to improve and enhance employee commitment. Two factors do not affect the long-term commitment of employees: the working environment and relationships with colleagues. Firstly, employees do not have to go directly to the factory to create products, so the working environment is relatively safe. According to state regulations, businesses must be fully equipped with fire prevention and fighting tools, and employees in the company must be trained on how to prevent fire so employees can feel secure when working. Moreover, businesses have not focused on building a working environment for employees but only on expertise and work efficiency, leading to a working environment that does not affect long-term commitment. Second, relationships with colleagues do not affect long-term commitment because teamwork is currently not prevalent in Vietnam. Employees often focus on their work and ignore colleagues. Furthermore, part of the reason is that the company has not created favourable conditions for employees to have the opportunity to interact with each other. As a result, it makes the relationship with colleagues not affected long-term on employee commitment. The authors will propose management implications and recommendations for the office staff of enterprises in Ho Chi Minh City.

Salary and bonuses $(\beta=0.363)$ are the maximum effect level, showing that employees are temporarily satisfied with the salary and bonus they receive each month. This result is consistent with previous research results that have shown that there is a positive relationship between compensation and the long-term commitment of employees (Ha \& Bui, 2016; N. P. Nguyen et al., 2020; T. T. Nguyen \& Ho, 2021; Pham \& Nguyen, 2013). The company needs to make sure that the income level of its employees ensures that they can meet the current average standard of living. Salary and bonuses must be paid based on the actual capacity of employees. Enterprises must publicise payroll and salary regulations to easily track, from which they can propose a salary if they feel not satisfied with their current income. In addition, the company should refer to the salary that other businesses in the same industry pay employees to offer a more reasonable salary and 
create trust for employees by paying in full and on time specified by the company.

Training and development opportunity is the second level of effect $(\beta=0.308)$. This result is consistent with previous research that confirmed that training and development factors positively influence employee commitment (Ha \& Bui, 2016; A. T. K. Nguyen et al., 2018; N. P. Nguyen et al., 2020; Pham \& Nguyen, 2013). Research results show that employees are temporarily satisfied with the company's training and development opportunities. Training and development provide businesses with high-quality human capital, contributing to improving competitiveness. The training also helps employees be trained with multiple skills, avoid stagnation, and quickly adapt to different jobs. Enterprises should have training and development policies to improve professional skills and soft skills for employees. In addition, the company needs to support time and part of the learning budget for employees, motivate and encourage employees to study and listen to lessons in a more focused and effective way. After training, it is necessary to check and evaluate the results to see the effectiveness of the training and the weaknesses that need to be overcome.

Employee benefits $(\beta=0.109)$ have the third effect on employee commitment. This result is consistent with previous studies. Accordingly, the authors have confirmed that welfare affects employees' long-term commitment to the enterprise (V. N. Bui, 2016; Do et al., 2012; A. T. K. Nguyen et al., 2018; N. P. Nguyen et al., 2020; N. V. Tran, 2015). Research results found that employees are temporarily satisfied with the company's welfare policy for them. Through welfare policies, the company's interest in employees will be shown through the purchase of insurance and periodic health checks. When employees are in good health, they will work more efficiently. In addition, the company should organise picnic programs and sightseeing tours more abundantly, build some other attractions, create excitement for employees, and contribute to building team spirit associated with the company.

\subsection{Limitations and future research}

The factors proposed by the authors, such as working environment, salary and bonuses, relationship with colleagues, employee benefits, training and development opportunities, are not enough. There are many other factors that previous studies mentioned, such as empowerment, organisational branding, nature of work, leadership, and many other factors that are not considered. Therefore, the subsequent research should consider more factors combined with geographical, social, and cultural differences to discover more factors. The research scope is only concentrated in Ho Chi Minh City with a convenient sampling technique, so the sample's representativeness is limited. Therefore, future research can be expanded to different groups of employees to be more representative.

\section{References}

Agyeiwaah, E., Dayour, F., \& Zhou, Y. (2021). How does employee commitment impact customers' attitudinal loyalty? Journal of Hospitality and Tourism Insights. doi:10.1108/JHTI-09-20200169

Allen, N. J., \& Meyer, J. P. (1990). The measurement and antecedents of affective, continuance and normative commitment to the organisation. Journal of Occupational Psychology, 63(1), 1-18.

Allen, N. J., \& Meyer, J. P. (1996). Affective, continuance, and normative commitment to the organisation: An examination of construct validity. Journal of Vocational Behavior, 49(3), 252-276. 
Angle, H. L., \& Perry, J. L. (1981). An empirical assessment of organisational commitment and organisational effectiveness. Administrative Science Quarterly, 26(1), 1-14.

Base Resources. (2019). Effective measurement of corporate culture: 3 metrics every manager needs to track. Retrieved May 10, 2021, from https://resources.base.vn/hr/3-chi-so-doluong-hieu-qua-van-hoa-doanh-nghiep-471

Basford, T. E., \& Offermann, L. R. (2012). Beyond leadership: The impact of coworker relationships on employee motivation and intent to stay. Journal of Management and Organization, 18(6), 807-817.

Bhatnagar, J. (2007). Predictors of organizational commitment in India: Strategic HR roles, organizational learning capability and psychological empowerment. The International Journal of Human Resource Management, 18(10), 1782-1811.

Bui, T. A., \& Pham, H. T. (2009). Giáo trình hành vi tổ chức [Organizational behavior]. Hanoi, Vietnam: Nhà Xuất Bản Đại học Kinh tế quốc dân.

Bui, V. N. (2016). Ảnh hưởng của các yếu tố VHDN đến sự gắn bó với tổ chức của nhân viên công ty cổ phần CMCTELECOM tại TPHCM [Impacts of Coporate Culture on Employee's Commitment at CMCTELECOM company in Ho Chi Minh City]. Tạp chí Kinh tế - kỹ thuật, 13(3), 91-92.

Do, H. T. L. (2008). Anh hưởng của văn hóa công ty đến sự cam kết gắn bó với tổ chức của các nhân viên làm việc trong các doanh nghiệp Tp HCM [Influences of Corporate Culture on Employee's Commitment among Employee in Ho Chi Minh City] (Master's thesis, University of Economics Ho Chi Minh City, Vietnam). Retrieved May 15, 2021, from http://digital.lib.ueh.edu.vn/handle/UEH/44222

Do, K. X., \& Le, L. K. (2015). Nghiên cứu sự gắn kết của nhân viên đối với tổng công ty xăng dầu quân đội [Researching the employee's commit to military oil company]. Tạp chí Khoa học - Công nghệ Thủy sản, 3, 115-121.

Do, T. P. T., Nguyen, N. V., \& Nguyen, H. T. D. (2012). Phân tích các nhân tố ảnh hưởng đến sự gắn kết lâu dài của nhân viên trẻ đối với doanh nghiệp [Analyzing the factors influencing the longterm commitment of young employee to corporations]. Tạp chí Phát triển và hội nhập, 7(17), 54-60.

EMSC. (2019). Tại sao sụ gắn bó của nhân viên lại quan trọng đối với doanh nghiệp? [Why is employee engagement important to your business?]. Retrieved May 15, 2021, from EMSC - Giải pháp phần mềm quản lý nhân sự hiệu quả webiste: https://emsc.vn/tai-sao-su-gan-bocua-nhan-vien-lai-quan-trong-doi-voi-doanh-nghiep/

Fernet, C., Gagné, M., \& Austin, S. (2010). When does quality of relationships with coworkers predict burnout over time? The moderating role of work motivation. Journal of Organizational Behavior, 31(8), 1163-1180.

Ha, G. N. K., \& Bui, V. N. (2016). Ảnh hưởng của các yếu tố văn hóa doanh nghiệp đến sự gắn bó với tổ chức của nhân viên Công ty Cổ phần CMC Telecom tại TP. Hồ Chí Minh [The influence of corporation culture on the staff's commitment in CMC Telecom HCMC]. Journal Economics-Technology, 13(3), 87-101.

Herzberg, F., Mausner, B., \& Snyderman, B. (1959). The motivation to work. New York, NY: John Wiley \& Sons. 
Ho, N. V., \& Nguyen, T. M. (2018). Mối quan hệ giữa các yếu tố tài chính với sự gắn kết trong công việc của nhân viên tại các ngân hàng TMCP tại thành phố Cần Thơ [The relationship between financial factors and employee engagement at joint stock commercial banks in Can Tho City]. Tạp chí Nghiên cưu khoa học và Phát triển kinh tế Trường Đại học Tây Đô, 04, 31-37.

Ho, T. H., \& Pham, L. H. (2012). Sự gắn kết của nhân viên với công ty du lịch Khánh Hòa [Employee engagement with Khanh Hoa tourism company]. Tạp chí Phát triển kinh tế, 264(10), 56-63.

Hoang, T., \& Chu, N. N. M. (2008). Phân tích dũ liệu nghiên cứu với SPSS [Analyze research data with SPSS]. Ho Chi Minh City, Vietnam: Hồng Đức Publishing.

Izogo, E. E., Elom, M. E., \& Mpinganjira, M. (2020). Examining customer willingness to pay more for banking services: The role of employee commitment, customer involvement and customer value. International Journal of Emerging Markets, 16(6), 1176-1201.

Jaros, S. J., Jermier, J. M., Koehler, J. W., \& Sincich, T. (1993). Effects of continuance, affective, and moral commitment on the withdrawal process: An evaluation of eight structural equation models. Academy of Management Journal, 36(5), 951-995.

Jaw, B. S., \& Liu, W. (2004). Towards an integrative framework of strategic international human resource control: The case of Taiwanese subsidiaries in the People's Republic of China. The International Journal of Human Resource Management, 15(4/5), 705-729.

John, P., \& Elyse, R. A. (2010). Employee commitment and well-being: A critical review, theoretical. Journal of Vocational Behaviour, 5(2), 134-145.

Macey-Dare, R. (2009). Practitioner problems for derivatives lawyers. Retrieved May 15, 2021, from https://ssrn.com/abstract=1530285

Man, A., \& Harter, J. (2016). The worldwide employee engagement crisis. Gallup Business Journal, 7(1), 1-5.

Maslow, A. H. (1954). Motivation and persionality. New York, NY: Harper and Row.

Mayer, R. C., \& Schoorman, F. D. (1992). Predicting participation and production outcomes through a two-dimensional model of organizational commitment. Academy of Management Journal, 35(3), 671-684.

Mayer, R. C., \& Schoorman, F. D. (1998). Differentiating antecedents of organisational commitment: A test of March and Simon's model. Journal of Organizational Behavior, 19(1), 15-28.

Meyer, J. P., \& Allen, N. J. (1991). A three-component conceptualization of organizational commitment. Human Resource Management Review, 1(1), 61-89.

Mowday, R., Steers, R., \& Porter, L. (1979). The measurement of organizational commitment. Journal of Vocational Behavior, 14, 224-247.

Nguyen, A. T. K., Nguyen, H. T. M., \& Do, M. N. (2018). Các nhân tố ảnh hưởng đến sự gắn kết người lao động với doanh nghiệp kinh doanh lưu trú và ăn uống vùng duyên hải Nam Trung bộ [Factors affecting employee engagement with accommodation and catering businesses in the South Central Coast]. Hue University Journal of Science: Economics and Development, 127(5A), 185-198. 
Nguyen, C. C. (2011). Các giải pháp tạo sụ gắn kết lâu dài của người lao động với doanh nghiệp ơ các đon vị thành viên VNPT Cần Tho [Solutions to create long-term cohesion of employees with enterprises at VNPT Can Tho]. Retrieved May 15, 2021, from http://115.74.210.103:81/tailieuso/bitstream/123456789/221/1/Tran\%20Quang\%20Thoai.p df

Nguyen, C., \& Duong, A. (2020). The impact of training and development, job satisfaction and job performance on young employee retention. International Journal of Future Generation Communication and Networking, 13(3), 373-386.

Nguyen, D. V. (2007). Các yếu tố ảnh hương đến sự thỏa mãn và sự gắn kết của nhân viên hợp tác xã thuong mai Tp HCM [Factors affecting satisfaction and engagement of commercial cooperative employees in Ho Chi Minh City] (Master's thesis, University of Economics Ho Chi Minh City, Vietnam). Retrieved May 15, 2021, from https://digital.lib.ueh.edu.vn/ handle/UEH/42867

Nguyen, D. V., \& Nguyen, Q. N. (2007). Quản trị nhân lục [Human resource management]. Hanoi, Vietnam: Nhà xuất bản Đại học Kinh tế quốc dân.

Nguyen, L. H. (1998). Hành vi tổ chức [Organisational behavior]. Ho Chi Minh City, Vietnam: Nhà xuất bản giáo dục.

Nguyen, N. P., Nguyen, H. T. N., Nguyen, H. T. T., \& Hoang, V. A. (2020). Nghiên cứu sự gắn kết của nhân viên đối với tổ chức trường hợp khách sạn 3 sao tại Đà Nẵng [Research on employee engagement in the case of a 3-star hotel in Da Nang]. Tạp chí Kinh tế và Phát triển, 276(6), 93-102.

Nguyen, T. H. (2006). Quản trị nhân sụ [Human resoure management]. Hanoi, Vietnam: Lao động - Xã hội Publishing.

Nguyen, T. T., \& Ho, D. T. (2021). Các nhân tố ảnh hưởng đến sụ thỏa mãn công việc, cam kết vớ tổ chưc [Factors affecting job satisfaction, commitment to the organization]. Retrieved March 10, 2021, from http://tapchicongthuong.vn/bai-viet/cac-nhan-to-anh-huong-den-suthoa-man-cong-viec-cam-ket-voi-to-chuc-va-y-dinh-o-lai-to-chuc-cua-nhan-vien-congnghe-thong-tin-tai-tp-ho-chi-minh-69223.htm

O'Reilly, C. A., \& Chatman, J. (1986). Organizational commitment and psychological attachment: The effects of compliance, identification, and internalization on prosocial behavior. Journal of Applied Psychology, 71(3), 492-499.

Paolini, S., Hewstone, M., \& Cairns, E. (2007). Direct and indirect intergroup friendship effects: Testing the moderating role of the affective-cognitive bases of prejudice. Personality and Social Psychology Bulletin, 33(10), 1406-1420.

Penley, L. E., \& Gould, S. (1988). Etzioni's model of organizational involvement: A perspective for understanding commitment to organizations. Journal of Organizational Behavior, 9(1), 43-59.

Pham, A. T., \& Nguyen, D. T. H. (2013). Quản trị nguồn nhân lực và sự gắn kết của người lao động với doanh nghiệp [Human Resource Management and Employee's Commitment to Corporation]. VNU Journal of Science: Economics and Business, 29(4), 24-34.

National Assembly. (2021). The Viet Nam labour code 2019. Retrieved July 07, 2021, from http://boluatlaodong2019.molisa.gov.vn/lang_en/topic/viet_nam_labour_code/index 
Sharar, D., Maynard, J., Christie, J., Derr, D., \& McLean, R. (2011). Employee assistance research foundation funds two research projects. Journal of Workplace Behavioral Health, 26(3), 167-174.

Teo, S. T., Bentley, T., \& Nguyen, D. (2020). Psychosocial work environment, work engagement, and employee commitment: A moderated, mediation model. International Journal of Hospitality Management, 88, Article 102415.

Tran, D. K. (2003). Quản trị nguồn nhân lục [Human resource management]. Hanoi, Vietnam: Nhà Xuất Bản Đại học Quốc Gia.

Tran, D. K., \& Morris, A. (2005). Đánh giá ý thức gắn kết với tổ chức và sự thỏa mãn công việc trong bối cảnh Việt Nam [Assessing the sense of belonging to the organization and job satisfaction in the context of Vietnam]. Hội nghị khoa học quốc tế tháng, 9.

Tran, N. V. (2015). Vai trò của sụ gắn kết giũua nhân viên và tổ chức trong thu hút, trọng dụng nhân tài [The role of the connection between employees and the organization in attracting and appreciating talents]. Retrieved May 15, 2021, from Tạp chí Tổ chức nhà nước website: https://tcnn.vn/news/detail/20940/Vai_tro_cua_su_gan_ket_giua_nhan_vien_va_to_chuc_t rong_thu_hut_trong_dung_nhan_taiall.html

Tran, T. Q. (2016). Các nhân tố ảnh hưởng đến sụ gắn kết công việc của nguời lao động [Factors affecting employee engagement] (Master's thesis, Tay Do University, Vietnam). Retrieved May 15, 2021, from http://115.74.210.103:81/tailieuso/bitstream/123456789/221/1/ Tran\% 20Quang\%20Thoai.pdf

Véronneau, M. H., Vitaro, F., Brendgen, M., Dishion, T. J., \& Tremblay, R. E. (2010). Transactional analysis of the reciprocal links between peer experiences and academic achievement from middle childhood to early adolescence. Developmental Psychology, 46(4), 773-790.

Yapp. (2009). Measuring the ROI of talent management. Strategic HR Review, 8(4), 5-10.

\section{Appendix 1. Questionnaire}

\begin{tabular}{|l|c|l|}
\hline Variables & Coding & Items \\
\hline \multirow{5}{*}{ Work environment } & MT1 & Safe working environment. \\
\cline { 2 - 3 } & MT2 & Enterprises provide complete support equipment for work. \\
\cline { 2 - 3 } & MT3 & Internal information exchange is easy. \\
\cline { 2 - 3 } & MT4 & Clean and cool workplace. \\
\cline { 2 - 3 } & MT5 & Your work environment is free of bullying or harassment. \\
\hline Salary And Bonuses & LT1 & Your current salary is commensurate with your ability. \\
\cline { 2 - 4 } & LT2 & Your salary meets the needs of life. \\
\cline { 2 - 3 } & LT3 & The salary offered by the company is better than other \\
& companies in the same industry. \\
\cline { 2 - 3 } & LT4 & Wages are paid in full and on time. \\
\cline { 2 - 3 } & LT5 & Can you suggest to the company your income level? \\
\hline Relationship With & DN1 & Your colleagues are sociable and happy. \\
\hline
\end{tabular}




\begin{tabular}{|c|c|c|}
\hline Variables & Coding & Items \\
\hline \multirow[t]{4}{*}{\begin{tabular}{|l|} 
Colleagues \\
\end{tabular}} & DN2 & Your colleagues are always ready to help. \\
\hline & DN3 & Your colleagues always cooperate to complete the job well. \\
\hline & DN4 & $\begin{array}{l}\text { Your professional level is enhanced when working with } \\
\text { colleagues. }\end{array}$ \\
\hline & DN5 & $\begin{array}{l}\text { Colleagues are always interested in encouraging you when you } \\
\text { have difficulties. }\end{array}$ \\
\hline \multirow{5}{*}{$\begin{array}{l}\text { Training and } \\
\text { Development } \\
\text { Opportunities }\end{array}$} & CH1 & The company gives you many opportunities for advancement. \\
\hline & CH2 & Fair promotion policy. \\
\hline & CH3 & $\begin{array}{l}\text { The company has activities to help you better understand your } \\
\text { abilities, goals, strengths and weaknesses. }\end{array}$ \\
\hline & CH4 & Your working skills are improved after being trained. \\
\hline & CH5 & You are offered in-depth training and development programs. \\
\hline \multirow[t]{5}{*}{ Employee benefits } & PL1 & The allowances are very reasonable. \\
\hline & PL2 & $\begin{array}{l}\text { The company does an excellent job of performing periodic } \\
\text { health checks for employees. }\end{array}$ \\
\hline & PL3 & $\begin{array}{l}\text { The company pays full insurance (health insurance, social } \\
\text { insurance) for employees. }\end{array}$ \\
\hline & PL3 & $\begin{array}{l}\text { The company regularly organises activities such as team } \\
\text { building, travel, and so on. }\end{array}$ \\
\hline & PL4 & The company offers a better welfare policy than others. \\
\hline \multirow[t]{5}{*}{$\begin{array}{l}\text { Employee } \\
\text { commitment }\end{array}$} & GB1 & $\begin{array}{l}\text { You will stay at the company even though other companies } \\
\text { offer more attractive salaries and benefits. }\end{array}$ \\
\hline & GB2 & You never intend to quit your job. \\
\hline & GB3 & $\begin{array}{l}\text { You will always stay and contribute to the company, even } \\
\text { though the company is facing difficulties. }\end{array}$ \\
\hline & GB4 & $\begin{array}{l}\text { You are very concerned about the situation and arising issues } \\
\text { affecting the company. }\end{array}$ \\
\hline & GB5 & $\begin{array}{l}\text { You see yourself having a future when working at the } \\
\text { company. }\end{array}$ \\
\hline
\end{tabular}

